\title{
Pengaruh Kompetensi dan Integritas terhadap Kinerja Perangkat Desa
}

\author{
Anton Sarni Eka Putra \\ Dinas Sosial, Pemberdayaan Masyarakat Desa, Perempuan, dan Perlindungan Anak, \\ Sawahlunto, Sumatera Barat \\ antonsarni@gmail.com
}

\begin{abstract}
This study aimed to analyze the effect of competence and integrity on the performance of the village apparatus of Sawahlunto City. This research used quantitative methods with associative descriptive research. This study consisted of two independent variables namely competency $(X 1)$ and integrity $(X 2)$ and one dependent variable, namely performance $(Y)$. The population of this study was all village apparatus of Sawahlunto City, amounting to 50 people. The sample was obtained through proportional random sampling, so that the respondents in this study amounted to 45 samples. The data analysis technique used was multiple regression. The data were collected through a questionnaire that had been validated and reliable in advance, both the content and the item empirical test in the field. The results of this study have found that: 1) There was an effect of competence on performance by $15.4 \%$ with a significance of $0.002 ; 2)$ There was an effect of integrity on performance of $20.5 \%$ with a significance of 0.001; and 3) There was an effect of competence and integrity simultaneously on performance by $45 \%$ with a significance of 0.000 .
\end{abstract}

Keywords: Employee; competence, integrity, performance

How to Cite: Putra, Anton Sarni Eka. 2021. Pengaruh Kompetensi dan Integritas terhadap Kinerja Perangkat Desa. Vol 5 (1): pp. 24-35. DOI: https://doi.org/10.24036/jess.v5i1

\section{Pendahuluan}

Perangkat desa adalah pelaksana dari kegiatan pemerintahan desa yang berhubungan langsung dengan masyarakat. Jika desa ingin memajukan desanya, perangkat desa harus memberikan kinerja yang lebih maksimal agar efektivitas kerja bisa dipertanggungjawabkan. Kinerja perangkat desa merupakan pencapaian hasil kerja atas tugas yang dilaksanakannya. Untuk meningkatkan pembangunan desa, maka diperlukan kinerja perangkat desa yang intensif dan optimal sehingga tujuan pemerintah desa dapat tercapai dengan baik.

Kinerja perangkat desa akan maksimal jika didukung dengan sumber daya manusia (SDM) yang kompeten di bidangnya. Karena SDM menyangkut tentang kesiapan dalam melaksanakan kerja, jumlah, tingkat pendidikan dan profesionalismenya, maka dari itu dibutuhkan pegawai yang berkualitas dan tepat untuk melaksanakan tugas pemerintahan desa.

Kinerja pemerintahan desa di Kota Sawahlunto selama ini memberikan pelayanan kepada masyarakat belum terlaksana secara maksimal. Adapun bentuk pelayanan yang diberikan oleh pemerintah desa di antaranya yaitu penyelesaian pengantar akta tanah, akta nikah, akta kelahiran, akta kematian, pembuatan KTP 
dan lain-lain. Hal ini terlihat dari kurang disiplinnya kinerja aparat desa, sehingga penyelesaiaan kerja para perangkat desa banyak terlambat dan tidak sesuai dengan prosedur penyelesaian kerja. Kadangkala, kantor desa ini ada yang kosong tanpa staf, dan pada saat jam kerja ada staf tidak bekerja dengan baik, sambil main internet sehingga pekerjaan banyak tidak diselesaikan tepat waktu. Perangkat desa masih banyak yang kurang memahami tugasnya dengan baik, hal ini diduga disebabkan tingkat pendidikan perangkat desa masih di bawah S1. Di samping itu perangkat desa kurang mempertanggungjawabkan hasil kerjanya yang kurang maksimal, sehingga hasil kerjanya cenderung hampir sama, tanpa ada perubahan. Rendahnya kinerja perangkat desa ini juga bisa dilihat dari tingkat kehadirannya dalam melaksanakan tugas di kantor.

Adapun faktor-faktor yang mempengaruhi perangkat desa dalam melaksanakan tugasnya dipengaruhi oleh faktor kompetensi dan integritas. Kompetensi perangkat desa merupakan salah satu yang mempengaruhi kinerja. Kompetensi perangkat desa sangat penting sekali untuk mencapai kinerja yang diharapkan oleh pemerintahan desa. Dengan adanya perangkat desa yang memiliki kompetensi yang sesuai dengan bidangnya, maka hasil kerja yang dicapai sesuai dengan target dibandingkan yang tidak memiliki kompetensi. Kinerja perangkat desa akan lebih baik jika ditunjang dengan kompetensi yang dimiliki sesuai dengan beban kerja yang dipikulnya seperti pengetahuan, keterampilan dan sikap yang dibutuhkan untuk menyelesaikan pekerjaan tersebut, sehingga pekerjaan dapat diselesaikan dengan optimal.

Kompetensi dari perangkat desa masih ada yang tidak tepat, di mana perangkat desa lebih banyak memiliki jenjang pendidikan tamatan SMA sederajat, bahkan ada yang tamatan SD. Hanya sedikit perangkat desa yang memiliki jenjang pendidikan Sarjana. Hal ini tentu berdampak terhadap kinerja perangkat desa dilihat dari jenjang pendidikan yang berkaitan dengan kompetensi yang dimilikinya. Hal ini sesuai dengan pendapat Moeheriono (2014) yang menyatakan bahwa kompetensi memiliki peran yang sangat besar, karena menyangkut dengan kemampuan yang dimiliki seseorang dalam melaksanakan pekerjaanya.

Saputra et al. (2016) menjelaskan bahwa kompetensi merupakan pengetahuan, kemampuan, dan keterampilan atau karakteristik personal seseorang yang menentukan tingkat perilaku dan keahlian individu dalam melakukan pekerjaannya yang diharapkan dapat memberikan kinerja yang unggul dalam pekerjannya. Ardiansyah \& Sulistiyowati (2018) mengemukakan bahwa seorang pegawai yang memiliki kompetensi terhadap suatu pekerjaan maka akan berdampak pada kinerjanya. Semakin tinggi kompetensi yang dimiliki oleh seorang pegawai, maka akan semakin baik pula kinerjanya. Begitupun sebaliknya, semakin rendah kompetensi yang dimiliki oleh seorang pegawai, maka akan semakin rendah pula kinerjanya. Kurangnya pengetahuan dan rendahnya keterampilan mengindikasikan bahwa masih rendahnya kompetensi pegawai. Maka dari itu peningkatan kompetensi harus terus dilakukan agar setiap pegawai mampu bekerja sesuai dengan tugas dan tangggungjawabnya (Sudarwati, 2014).

Faktor kedua yang mempengaruhi kinerja perangkat desa yaitu integritas. Integritas merupakan salah satu unsur kompetensi yang harus dimiliki oleh perangkat desa. Hal ini disebabkan karena perangkat desa yang memiliki integritas 
yang tinggi akan mampu menciptakan budaya berintegritas dengan pemerintahan desa sehingga menciptakan lingkungan kerja yang bernilai. Umar et al. (2016) menyatakan bahwa dengan adanya integritas yang tinggi akan mampu mendorong standar prestasi kerja tinggi, yang ditunjang dengan kecerdasan, jenjang pendidikan serta pelatihan untuk memperoleh kredit point kinerja.

Integritas berkaitan langsung dengan individu yang ada dalam organisasi. Individu yang dapat diandalkan dalam melaksanakan pekerjaan dengan optimal yaitu individu yang memiliki integritas yang lebih tinggi (Gea, 2014). Hasil penelitian Felisiana Andini Permatasari, Ni Luh Gede Erni Sulindawati, Edy Sujana (2016) dan Kirana (2016) menemukan bahwa terdapat pengaruh yang positif serta signifikan antara integritas terhadap kinerja. Hal ini berarti semakin besar integritas seseorang, maka kinerjanya akan lebih baik. Sebaliknya penelitian Ariani (2015) menemukan bahwa integritas berpengaruh signifikan terhadap kinerja. Sementara Oktavia (2019) menyatakan bahwa integritas berpengaruh positif terhadap kinerja auditor. Masih banyak lagi penelitian lain yang menemukan bahwa integritas berpengaruh terhadap kinerja pegawai, seperti Febrina dan Syamsir (2020), Tasi dan Syamsir (2020), Wahyuni dan Syamsir (2020), serta Rosmi dan Syamsir (2020), dalam beberapa penelitian mereka di lingkungan pegawai negeri sipil di Kota Sawahlunto, Kabupaten Sijunjung, Kabupaten Kerinci, dan Kabupaten Bungo menemukan bahwa integritas dan beberapa variabel lain mempengaruhi kinerja pegawai secara signifikan.

Penelitian ini bertujuan untuk menganalisis: (1) Pengaruh kompetensi terhadap kinerja perangkat desa di Kota Sawahlunto, (2) Pengaruh integritas terhadap kinerja perangkat desa di Kota Sawahlunto, (3) Pengaruh kompetensi dan integritas terhadap kinerja perangkat desa di Kota Sawahlunto. Hasil penelitian ini diharapkan memberikan kontribusi bagi perkembangan teori Administrasi Publik khususnya masalah kompetensi, integritas dan kinerja. Penelitin ini juga diharapkan dapat menambah khasanah pengetahuan dan pemahaman serta dapat dijadikan referensi pengetahuan, bahan diskusi dan bahan kajian lanjut bagi pembaca, memberikan informasi bagi seluruh perangkat desa di Kota Sawahlunto tentang tingkat kinerjanya selama ini serta menjadi bahan masukan dan pembanding bagi camat untuk meningkatkan kinerja perangkat desa di wilayahnya.

\section{Tinjauan Kepustakaan}

Kompetensi yang dimiliki oleh seorang karyawan merupakan suatu yang sangat diperlukan untuk menjawab kebutuhan organisasi dalam menghadapi perubahan lingkungan yang sangat cepat. Robbins (2015) kompetensi adalah keterampilan dan kemampuan untuk melakukan aktivitas kerja yang diperlukan dalam menciptakan nilai utama bagi organisasi. Sutrisno (2011) kompetensi dijelaskan sebagai karakteristik individu yang berhubungan dengan efektifitas kinerja individu dalam pekerjaannya.

Kasmir (2016) menjelaskan bahwa kinerja dipengaruhi oleh faktor kompetensi, pemahaman, rancangan kerja, kepribadian, motivasi kerja, gaya kepemimpinan, kepuasan kerja, budaya kerja, lingkungan kerja dan komitmen. Sedangkan Mahmudi (2015) menyatakan bahwa faktor-faktor yang mempengaruhi 
kinerja adalah faktor personal/individual meliputi pengetahuan, skill, kepercayaan diri, kompetensi, disiplin, motivasi, komitmen yang dimiliki individu, faktor kepemimpinan, faktor tim, faktor sistem dan faktor kontesktual (situasional).

Menurut Salwa et al. (2018) kompetensi pegawai yang baik sangat penting manfaatnya untuk kelangsungan sebuah organisasi, semakin tinggi tingkat kompetensi seseorang pegawai maka kemampuan dalam menyelesaikan pekerjaan akan semakin baik. Kompetensi menujukkan pengetahuan, keterampilan dan sikap tertentu dari sutu profesi dalam ciri keahlian tertentu yang menjadi ciri dari seorang profesional.

Romberg (dalam Rosmaini, 2019) menyatakan bahwa seorang pegawai memiliki kompetensi yang tinggi apabila pegawai tersebut memiliki pengalaman kerja, latar belakang pendidikan yang mendukung profesi, memiliki keahlian/pengetahuan dan memiliki keterampilan. Pengalaman kerja dapat meningkatkan kinerja, karena seseorang pegawai akan menempatkan diri tepat secara kondisi, berani mengambil resiko, kinerja dan menghasilkan individu yang kompeten.

Selanjutnya menurut Wurangin (2012) integritas merupakan pengakuan professional seseorang yang didasari oleh amalan karakter. Integritas akan membuat seseorang untuk berlaku jujur dan terbuka. Sedangkan menurut Syamsir dan Embi (2020) dan Rosmi dan Syamsir (2020) integritas adalah kesesuaian antara hati, ucapan dan tindakan. Integritas juga dapat didefinisikan sebagai kemampuan untuk senantiasa memegang teguh prinsip-prinsip moral dan menolak untuk mengubahnya walaupun kondisi dan situasi yang dihadapi sangat sulit, serta banyak tantangan yang berupaya untuk melemahkan prinsip-prinsip moral dan etika yang dipegang teguhnya. Disamping itu, Antonius (2012) berpendapat bahwa integritas diri merupakan kesatuan yang terdiri dari nilai yaitu spiritualitas, mentalitas (otonomi), sosial yang terkait dan tonus (fisik). Sementara Zahra (2011) berpendapat integritas merupakan komitmen seseorang dalam melaksanakan sesuatu hal yang didasari oleh prinsip yang benar dan etis, nilai yang berlaku, dan norma serta konsisten dalam melakukan komitmen tersebut baik pada situasi tanpa melihat peluang atau paksaan untuk keluar dari prinsip yang diyakinanya. Menurut Prameswari (2015) integritas merupakan kualitas yang menjadikan timbulnya kepercayaan masyarakat dan tata nilai tertinggi bagi anggota profesi dalam menguji semua keputusan. Di sisi lain, Wetik et al. (2018) berpendapat bahwa integritas adalah suatu sikap di mana seorang pegawai diharuskan untuk bersikap jujur, berani, bijaksana dan bertanggung jawab.

Perilaku seseorang akan mempengaruhi sikapnya untuk menjalankan kehidupan dan kegiatan dalam organisasi bisnis atau publik, sehingga apabila seorang pegawai mempunyai integritas yang baik akan mempengaruhi kinerja pegawai itu menjadi meningkat (Astuti 2013). Integritas merupakan kondisi yang diperlukan untuk mencapai kinerja yang maksimum. Artinya jika suatu integritas dapat dilaksanakan secara utuh, lengkap, dan tak terputus, maka tentu hal tersebut akan memiliki dampak work ability yang maksimun (Yolanda and Syamsir 2020). 


\section{Metode Penelitian}

Jenis Penelitian ini adalah deskriptif asosiatif. Populasi dalam Penelitian ini adalah perangkat desa pada lima desa di empat kecamatan yang ada di Kota Sawahlunto yang berjumlah 50 orang. Sampel dalam Penelitian ini sebanyak 45 orang dengan teknik pengambilan sampel yang digunakan yaitu proportional random sampling. Data yang dikumpulkan dalam penelitian ini menggunakan angket/kuesioner. Angket dalam penelitian ini disusun dalam bentuk pernyataan-pernyataan sesuai dengan indikator yang digunakan pada variabel penelitian. Angket yang digunakan yaitu angket tertutup. Analisis data yang digunakan untuk menjawab uji hipotesis yaitu analisis regresi berganda.

Definisi operasional dari masing-masing variabel diuraikan sebagai berikut; Kinerja (Y) perangkat desa merupakan prestasi atau hasil kerja baik kualitas maupun kuantitas yang dicapainya persatuan periode waktu dalam melaksanakan tugas kerjanya sesuai dengan tanggung jawab yang diberikan kepadanya. Indikator kinerja digunakan yaitu: (1) kuantitas kerja, (2) kualitas kerja, (3) keandalan, (4) ketepatan waktu dan (5) sikap. Kompetensi (X1) adalah kemampuan yang dimiliki oleh perangkat desa untuk melaksanakan atau melakukan pekerjaan yang dilandasi oleh keterampilan serta pengetahuan dan sikap kerja yang sesuai dengan pekerjaan tersebut. Adapun indikator kompetensi yang digunakan dalam penelitian ini yaitu pengetahuan, keterampilan dan sikap. Integritas (X2) adalah elemen karakter yang mendasari pengakuan profesional. Integritas mengharuskan seorang anggota untuk bersikap jujur dan berterus terang. Adapun yang menjadi indikator integritas yaitu: berhasil melawan egoisme, bersikap jujur dan terbuka, perhitungan pengorbanan, bertindak bijak dan berperilaku luhur dalam bertindak.

\section{Hasil dan Pembahasan}

Analisis yang digunakan dalam penelitian ini adalah analisis regresi linier berganda dengan tiga predictor yaitu kompetensi (X1), integritas (X2) dan kinerja (Y). Model regresi ini dapat digunakan untuk mengetahui bentuk pengaruh kompetensi (X1) dan integritas (X2) terhadap perangkat desa di Kota Sawahlunto secara simultan dan parsial. Berdasarkan hasil perhitungan SPSS versi 22 diperoleh tabel analisis regresi sebagai berikut:

Tabel 1. Analisis Regresi Berganda

\begin{tabular}{|c|c|c|c|c|c|c|c|c|}
\hline \multirow{2}{*}{\multicolumn{2}{|c|}{ Model }} & \multicolumn{2}{|c|}{$\begin{array}{l}\text { Unstandardized } \\
\text { Coefficients }\end{array}$} & $\begin{array}{l}\text { Standardized } \\
\text { Coefficients }\end{array}$ & \multirow{2}{*}{$\mathbf{T}$} & \multirow{2}{*}{$\begin{array}{l}\text { Sig. } \\
\mathbf{H}_{\mathbf{0}}\end{array}$} & \multicolumn{2}{|c|}{ Keterangan } \\
\hline & & B & $\begin{array}{l}\text { Std. } \\
\text { Error }\end{array}$ & Beta & & & $\mathbf{H}_{\mathbf{0}}$ & $\mathbf{H}_{1}$ \\
\hline \multirow[t]{3}{*}{1} & (Constant) & 7.378 & 8.348 & & .884 & .382 & - & $\sqrt{ }$ \\
\hline & Kompetensi & .545 & .140 & .454 & 3.882 & .000 & - & $\sqrt{ }$ \\
\hline & Integritas & .448 & .104 & .506 & 4.324 & .002 & - & $\sqrt{ }$ \\
\hline
\end{tabular}

a. Dependent Variable: Kinerja

Sumber: Hasil Olahan Data Penelitian, SPSS 22, 2020 
Tabel di atas menunjukkan bahwa persamaan regresi berganda yang diperoleh dari hasil analisis, sebagai berikut:

$\mathrm{Y}=7,378+0,545 \mathrm{X}_{1}+0,448 \mathrm{X}_{2}$

Model regresi tersebut mempunyai makna bahwa dengan hasil konstanta $=7,378$ berarti bahwa jika variabel kompetensi $\left(\mathrm{X}_{1}\right)$ dan integritas $\left(\mathrm{X}_{2}\right)$ dianggap konstan, maka rata-rata kinerja perangkat desa turun sebesar 7,378.

\section{a. Pengaruh Kompetensi terhadap Kinerja}

Dari perhitungan regresi berganda diperoleh nilai coefficients $\left(\mathrm{b}_{1}\right)$ adalah 0,545 . Hal ini berarti jika variabel kompetensi mengalami peningkatan sebesar 1 (satu) poin, sementara variabel integritas $\left(\mathrm{X}_{2}\right)$. dianggap tetap maka akan menyebabkan kenaikan kinerja $(\mathrm{Y})$ sebesar 0,545. Bagi variabel kompetensi $\left(\mathrm{X}_{1}\right)$ diperoleh nilai signifikansi 0,000 atau $0 \%$ dimana $0,000<0,05$ sehingga $\mathrm{H}_{0}$ ditolak dan $\mathrm{Ha}$ diterima. dengan signifikansi $0 \%$, berarti variabel kompetensi $\left(\mathrm{X}_{1}\right)$ dapat dipercaya dengan $100 \%$ berpengaruh signifikan terhadap kinerja perangkat desa di Kota Sawahlunto.

Hal ini menunjukkan bahwa apabila kompetensi perangkat di desa Kota Sawahlunto semakin ditingkatkan maka kinerja perangkat desa di Kota Sawahlunto akan semakin meningkat. Perangkat desa dalam melaksanakan tugas atau pekerjaan sangat ditentukan oleh kompetensi yang sesuai dengan bidang pekerjaan. Melalui kompetensi yang semakin memadai dan sesuai dengan pekerjaan maka perangkat desa akan lebih menguasai dan mampu melaksanakan tugas pekerjaan sesuai dengan job description yang ditetapkan sehingga tingkat kinerja meningkat.

\section{b. Pengaruh Integritas terhadap Kinerja}

Dari perhitungan regresi berganda diperoleh nilai coefficients $\left(b_{2}\right)$ adalah 0,448 . Hal ini berarti jika variabel integritas $\left(\mathrm{X}_{2}\right)$ mengalami peningkatan sebesar 1 (satu) poin, sementara variabel kompetensi $\left(\mathrm{X}_{1}\right)$ dianggap tetap maka akan menyebabkan kenaikan kinerja (Y) sebesar 0,448.

Variabel integritas $\left(\mathrm{X}_{2}\right)$ diperoleh nilai signifikansi 0,002 dimana $0,002<$ 0,05 sehingga $\mathrm{H}_{0}$ ditolak dan Ha diterima. Hal ini berarti variabel integritas $\left(\mathrm{X}_{2}\right)$ dapat dipercaya dengan 99,8\% berpengaruh signifikan terhadap kinerja perangkat desa di Kota Sawahlunto. Hal ini berarti bila perangkat desa di Kota Sawahlunto memiliki integritas yang tinggi maka kinerjanya akan meningkat. Integritas yang tinggi memberikan dorongan dan semangat yang tinggi bagi perangkat desa untuk melaksanakan tugasnya dengan baik.

\section{c. Pengaruh Kompetensi dan Integritas terhadap Kinerja}

Uji $\mathrm{F}$ digunakan untuk mengetahui apakah variabel-variabel independen secara simultan berpengaruh signifikan terhadap variabel dependen. Derajat kepercayaan yang digunakan adalah 0,05 . Apabila nilai $F$ hasil perhitungan lebih besar daripada nilai $\mathrm{F}$ menurut tabel maka hipotesis alternatif, yang menyatakan bahwa semua variabel independen secara simultan berpengaruh signifikan terhadap variabel dependen. Untuk analisisnya dari output SPSS dapat dilihat dari tabel di bawah ini: 
Tabel 2. Hasil Uji Simultan (F)

\begin{tabular}{|c|c|c|c|c|c|}
\hline \multirow{2}{*}{ Model } & \multirow{2}{*}{ Df } & \multirow{2}{*}{$\mathbf{F}$} & \multirow{2}{*}{ Sig. } & \multicolumn{2}{|c|}{ Keterangan } \\
\hline & & & & $\mathbf{H}_{\mathbf{0}}$ & $\mathbf{H}_{1}$ \\
\hline Regression & 2 & & & & \\
\hline Residual & 42 & 15.725 & $.000^{\mathrm{a}}$ & - & $\sqrt{ }$ \\
\hline Total & 44 & & & & \\
\hline
\end{tabular}

Sumber : Hasil Olahan Data Penelitian, SPSS 22, 2020

Dari tabel diperoleh nilai $\mathrm{F}$ sebesar 15.725 dengan nilai probabilitas $($ sig) $=0,000$. Nilai F sebesar 15,725 dan nilai sig. lebih kecil dari nilai probabilitas 0,05 atau nilai $0,000<0,05$; maka $\mathrm{H} 1$ diterima, berarti secara bersama-sama (simultan) kompetensi $\left(\mathrm{X}_{1}\right)$ dan integritas $\left(\mathrm{X}_{2}\right)$ berpengaruh terhadap kinerja perangkat desa di Kota Sawahlunto. Hal ini menunjukkan apabila kompetensi perangkat desa sesuai dengan bidang pekerjaannya, maka kinerja perangkat desa di Kota Sawahlunto akan mengalami peningkatan. Hal ini harus didukung dengan integritas perangkat desa, dimana integritas yang tinggi akan mendorong semangat mereka untuk melaksanakan kinerja dengan baik sesuai visi dan misi yang telah ditetapkan oleh pemerintah desa.

\section{d. Uji Koefisien Determinasi}

Koefisien determinasi $\left(\mathrm{r}^{2}\right)$ berguna untuk menunjukkan seberapa besar kontribusi variabel bebas terhadap variabel terikat. Tabel di bawah menunjukkan tingkat hubungan kompetensi $\left(\mathrm{X}_{1}\right)$ terhadap kinerja perangkat desa di Kota Sawahlunto. Selanjutnya untuk lebih jelasnya dapat dilihat pada tabel berikut:

Tabel 3. Koefisien Determinasi kompetensi $\left(\mathrm{X}_{1}\right)$ terhadap Kinerja Perangkat Desa di Kota Sawahlunto

\begin{tabular}{ccccc}
\hline Model & R & R Square & Adjusted R Square & Std. Error of the Estimate \\
\hline 1 & $.417^{\mathrm{a}}$ & .174 & .154 & 4.80700 \\
\hline
\end{tabular}

a. Predictors: (Constant), Kompetensi

Sumber : Hasil Olahan Data Penelitian, SPSS 22, 2020

Berdasarkan Tabel 3 di atas, dapat dilihat nilai Adjusted R Square sebesar 0,154. Hal ini berarti besar kontribusi antara kompetensi $\left(\mathrm{X}_{1}\right)$ terhadap kinerja perangkat desa di Kota Sawahlunto adalah 0,154 atau 15,4\%. Koefisien determinasi $\left(\mathrm{r}^{2}\right)$ berguna untuk menunjukkan seberapa besar kontribusi variabel bebas terhadap variabel terikat. Selanjutnya Tabel 4 di bawah menunjukkan tingkat hubungan integritas $\left(\mathrm{X}_{2}\right)$ terhadap kinerja perangkat desa di Kota Sawahlunto. 
Tabel 4. Koefisien Determinasi Integritas $\left(\mathbf{X}_{2}\right)$ terhadap Kinerja Perangkat Desa di Kota Sawahlunto

\begin{tabular}{ccccc}
\hline Model & R & R Square & Adjusted R Square & Std. Error of the Estimate \\
\hline 1 & $.472^{\mathrm{a}}$ & .223 & .205 & 4.66120 \\
\hline
\end{tabular}

a. Predictors: (Constant), Integritas

Sumber : Hasil Olahan Data Penelitian, SPSS 22, 2020

Berdasarkan Tabel 4 di atas, dapat dilihat nilai Adjusted R Square sebesar 0,205. Hal ini berarti besar kontribusi antara integritas $\left(\mathrm{X}_{2}\right)$ terhadap kinerja perangkat desa di Kota Sawahlunto adalah 0,205 atau 20,5\%. Koefisien determinasi $\left(\mathrm{r}^{2}\right)$ berguna untuk menunjukkan seberapa besar kontribusi variabel bebas terhadap variabel terikat.

Tabel 5. Koefisien Determinasi Kompetensi $\left(X_{1}\right)$ dan Integritas $\left(X_{2}\right)$ terhadap Kinerja Perangkat Desa di Kota Sawahlunto

\begin{tabular}{ccccc}
\hline Model & R & R Square & Adjusted R Square & Std. Error of the Estimate \\
\hline 1 & $.654^{\mathrm{a}}$ & .428 & .401 & 4.04608 \\
\hline
\end{tabular}

a. Predictors: (Constant), Kecerdasan emosional, Kompetensi, Integritas

Sumber : Hasil Olahan Data Penelitian, SPSS 22, 2020

Berdasarkan Tabel 5 di atas, dapat dilihat nilai Adjusted R Square sebesar 0,401. Hal ini berarti besar kontribusi antara Kompetensi $\left(\mathrm{X}_{1}\right)$ dan Integritas $\left(\mathrm{X}_{2}\right)$ terhadap kinerja perangkat desa di Kota Sawahlunto adalah 0,401 atau 40,1\%.

Berdasarkan hasil analisis diperoleh persamaan regresi untuk memprediksi kenaikan atau penurunan kinerja perangkat desa di Kota Sawahlunto di masa yang akan datang dengan kompetensi $\left(\mathrm{X}_{1}\right)$ dan integritas $\left(\mathrm{X}_{2}\right)$ sebagai prediktornya. Berdasarkan hasil analisis regresi dengan bantuan program SPSS 22.0 menunjukkan bahwa 4 hipotesis yang diajukan diterima. Adapun pembahasannya adalah sebagai berikut :

\section{Pengaruh Kompetensi terhadap Kinerja}

Dari hasil persamaan regresi diperoleh hasil variabel kompetensi $\left(\mathrm{X}_{1}\right)$ berpengaruh yang signifikan terhadap kinerja perangkat desa di Kota Sawahlunto. Hal ini sesuai dengan teori atau temuan yang dikemukakan oleh Sudarwati (2014). Seorang pegawai yang memiliki kompetensi terhadap suatu pekerjaan, maka akan berdampak pada kinerjanya. Semakin tinggi kompetensi yang dimiliki oleh seorang pegawai, maka akan semakin baik pula kinerjanya. Begitupun sebaliknya, semakin rendah kompetensi yang dimiliki oleh seorang pegawai, maka akan semakin rendah pula kinerjanya. Kurangnya pengetahuan dan rendahnya keterampilan mengindikasikan bahwa masih rendahnya kompetensi pegawai. Maka dari itu, peningkatan kompetensi harus terus dilakukan agar setiap pegawai mampu bekerja sesuai dengan tugas dan tanggungjawabnya. 
Hasil penelitian ini sesuai dengan teori yang dikemukakan oleh Grote (dalam Pramudyo, 2013) bahwa kompetensi dapat digunakan untuk memprediksi kinerja yaitu siapa yang berkinerja baik dan kurang baik tergantung pada kompetensi yang dimilikinya. Diukur dari kriteria atau standar yang digunakan. Hasil penelitian ini juga sejalan dengan penelitian Wetik et al. (2018) bahwa kompetensi berpengaruh positif dan signifikan secara langsung terhadap kinerja. Hasil penelitian Permatasari (2017) juga menunjukkan bahwa kompetensi berpengaruh signifikan secara parsial terhadap kinerja.

\section{Pengaruh Integritas terhadap Kinerja}

Hasil perhitungan koefisien regresi diperoleh hasil bahwa variabel integritas $\left(\mathrm{X}_{2}\right)$ berpengaruh yang signifikan terhadap terhadap kinerja perangkat desa di Kota Sawahlunto. Hasil penelitian ini sejalan dengan teori Mutchler (dalam Umar et al. 2016) bahwa integritas yang tinggi maka akan dapat mempertahankan standar prestasi yang tinggi dan melakukan kompetensi yang berarti memiliki kecerdasan, pendidikan dan pelatihan untuk dapat nilai tambah melalui kinerja.

Hal ini sejalan dengan penelitian Wetik et al. (2018) yang menemukan bahwa integritas berpengaruh positif dan signifikan secara langsung terhadap kinerja pada kantor Kesyahbandaran dan Otoritas Pelabuhan Kota Manado. Yusnaena (2013) berdasarkan hasil penelitiannya juga menemukan bahwa terdapat pengaruh yang signifikan antara integritas karyawan terhadap kinerja karyawan Sekretariat Daerah Kabupaten Pesisir Selatan. Yolanda \& Syamsir (2020) menemukan bahwa semua sub variabel integritas (terdiri dari kejujuran, komitmen dan konsistensi) berpengaruh signifikan terhadap kinerja PNS Lembaga Pemerintah Daerah di Kota Padang. Begitu juga hasil penelitian Febrina dan Syamsir (2020), Tasi dan Syamsir (2020), Wahyuni dan Syamsir (2020), serta Rosmi dan Syamsir (2020), dalam beberapa penelitian mereka di lingkungan pegawai negeri sipil di Kota Sawahlunto, Kabupaten Sijunjung, Kabupaten Kerinci, dan Kabupaten Bungo menemukan bahwa integritas dan beberapa variabel lain mempengaruhi kinerja pegawai secara signifikan.

Sujiyanto (2017) juga mengemukakan bahwa integritas berpengaruh signifikan terhadap kinerja pegawai yang ada pada Dinas Komunikasi dan Informatika Kota Batu, hal ini menunjukkan bahwa semakin tinggi integritas yang dimiliki pegawai terhadap organisasi tempat dia bekerja maka kinerja yang ditunjukkan oleh pegawai tersebut juga akan mengalami peningkatan yang cukup signifikan secara tidak langsung kinerja organisasi perangkat desa juga akan mengalami peningkatan.

\section{Pengaruh Kompetensi dan Integritas Secara Bersama-Sama terhadap Kinerja}

Hasil penelitian menunjukkan bahwa terdapat pengaruh yang positif dan signifikan antara Kompetensi $\left(\mathrm{X}_{1}\right)$ dan Integritas $\left(\mathrm{X}_{2}\right)$ secara simultan terhadap kinerja perangkat desa di Kota Sawahlunto. Hal ini dibuktikan dari hasil uji F dengan F tabel sebesar 13,011 dengan signifikan 0,000. Kontribusi Kompetensi $\left(\mathrm{X}_{1}\right)$ dan Integritas $\left(\mathrm{X}_{2}\right)$ yang secara simultan mempengaruhi kinerja perangkat desa di Kota Sawahlunto dapat dilihat dengan nilai Adjusted R Square sebesar 0,428 atau 42,8\%. 
Hasil penelitian ini sejalan dengan pendapat Ardiansyah \& Sulistiyowati, (2018), membuktikan bahwa terdapat pengaruh yang positif dan signifikan baik secara parsial maupun simultan antara variabel kompetensi dan kecerdasan emosional terhadap kinerja pegawai. Panggabean (2017) juga menyatakan bahwa variabel integritas dan kompetensi berpengaruh signifikan terhadap kinerja personel satuan Lantas Polres Cilacap. Salwa et al. (2018) menyatakan bahwa komitmen, integritas dan kompetensi berpengaruh positif terhadap kinerja

\section{Penutup}

Berdasarkan hasil uji hipotesis yang telah dilakukan sebelumnya, dapat diperoleh kesimpulan sebagai berikut: (1) Kompetensi berpengaruh signifikan terhadap kinerja perangkat desa di Kota Sawahlunto. Hal ini menunjukkan bahwa apabila kompetensi perangkat desa semakin ditingkatkan maka kinerja perangkat desa akan semakin meningkat. (2) Integritas berpengaruh signifikan terhadap kinerja perangkat desa di Kota Sawahlunto. Hal ini berarti bila integritas perangkat desa tinggi, maka kinerja perangkat desa akan meningkat. (3) Kompetensi dan integritas secara bersama-sama mempengaruhi kinerja perangkat desa di Kota Sawahlunto.

\section{Ucapan Terima Kasih}

Terima kasih peneliti sampaikan kepada Kepala Desa Silungkang Duo yaitu Bapak Wandi, Kepala Desa Lunto Timur yaitu Bapak Wetrianto, Kepala Desa Santua yaitu Bapak Sri Adianto, Kepala Desa Data Mansiang yaitu Bapak Afrinal dan Kepala Desa Batu Tanjung yaitu Bapak Marwan, S.Pd. SD Yang telah mengizinkan dan membantu penelitian ini di desa yang dipimpin, sehingga penelitian ini bisa berjalan dengan lancar dan tepat, serta kepada Perangkat desa pada lima desa diatas yang telah memberikan jawaban terkait pertanyaan yang telah diajukan

\section{DAFTAR KEPUSTAKAAN}

Antonius. 2012. Manajemen Sumber Daya Manusia: Strategi Dan Perubahan Dalam Rangka Meningkatkan Kinerja Pegawai Dan Organisasi. Bandung: Alfabeta.

Ardiansyah, Yusuf, and Lisa Harry Sulistiyowati. 2018. "Pengaruh Kompetensi Dan Kecerdasan Emosional Terhadap Kinerja Pegawai." Jurnal Inspirasi Bisnis Dan Manajemen 2(1):91. doi: 10.33603/jibm.v2i1.1064.

Ariani, Komang Gunayanti. 2015. "Pengaruh Integritas, Obyektifitas,

Kerahasiaan, Dan Kompetensi Pada Kinerja Auditor Inspektorat Kota

Denpasar." E-Jurnal Akuntansi Universitas Udayana 10.1 1:182-98.

Astuti, Y. D. 2013. "Hubungan Budaya Organisasi Dengan Karyawan Di PT. PLN (Persero) Area Malang. 14."

Febrina, Dita, and Syamsir. 2020. "The Influence of Integrity and Commitment

Organizational on Employee Performance.” International Journal of

Research and ... 7(1):799-805.

Felisiana Andini Permatasari ., Ni Luh Gede Erni Sulindawati, SE. Ak, M ., Dr. Edy Sujana, SE, Msi, AK. 2016. "Pengaruh Komitmen Profesi, Integritas, 
Objektivitas, Kompetensi, dan Perilaku Profesional terhadap Kinerja Auditor (Studi Empiris Pada Inspektorat Pemerintah Provinsi Bali, Kabupaten Bangli, Dan Kabupaten Klungkung).” Jurnal Ilmiah Mahasiswa Akutansi Undiksha 4(01). doi: http://dx.doi.org/10.23887/jimat.v4i1.6654.

Gea, Antonius Atosokhi. 2014. Integritas Personal Dan Kepemimpinan Etis. Jakarta: Binus University.

Kasmir. 2016. Manajemen Sumber Daya Manusia (Teori Dan Praktik). Jakarta: PT. Raja Grafindo Persada.

Kirana, Nita Eka. 2016. "Pengaruh Independensi, Integritas, Objektivitas Dan Kerahasiaan Terhadap Kinerja Auditor Pada Kantor Inspeksi Bank BRI Yogyakarta." E-Jurnal Universitas Negeri Yogyakarta 1.

Mahmudi. 2015. Manajemen Kinerja Sektor Publik Edisi Kedua. Yogyakarta: UPP STIM YKPN.

Moeheriono. 2014. Pengukur Kinerja Berbasis Kompetensi. Jakarta: Ghalia Indonesia.

Oktavia, Marta Hapsari. 2019. "Pengaruh Integritas, Kerahasiaan, Kompleksitas Tugas, Motivasi Dan Ketidakjelasan Peran Terhadap Kinerja Auditor Di Inspektorat Provinsi Jawa Tengah.” Jurnal Akuntansi Bisnis 16(2):161. doi: 10.24167/jab.v16i2.2253.

Panggabean, Rio Rinaldy. 2017. "Pengaruh Kompetensi Dan Integritas Terhadap Kinerja Personel Satuan Lantas Polres Cilacap." Advances in Police Science Research Journal 1.

Permatasari, Intan. 2017. "Pengaruh Independensi Dan Kompetensi Auditor Terhadap Kualitas Audit Internal.” Jurnal Akutansi, Audit dan Sistem Informasi Akutansi (JASa) 1(4):77-85.

Prameswari, Dwi Anjani. 2015. "Kerahasiaan, Kompetensi Dan Komitmen Organisasi Terhadap Kinerja Internal Auditor ( Studi Kasus Pada Inspektorat Jenderal Kementerian Kesehatan Ri ) the Influence of Integrity, Objectivity, Confidentiality, Competence and Organization Commitment To Th." 2(3):3229-36.

Pramudyo, Anung. 2013. "Analisis Faktor-Faktor Yang Mempengaruhi Kinerja Dosen Negeri Pada Kopertis Wilayah V Yogyakarta.” Journal of Chemical Information and Modeling 01(01):1689-99.

Robbins, Stephen P. 2015. Perilaku Organisasi. 16th ed. Jakarta: Salemba Empat. Rosmaini, Hasrudy Tanjung. 2019. "Pengaruh Kompetensi, Motivasi Dan Kepuasan Kerja Terhadap Kinerja Pegawai.” Maneggio: Jurnal Ilmiah Magister Manajemen 2(1):1-15. doi: 10.30596/maneggio.v2i1.3366.

Rosmi, Rosmi, and Syamsir Syamsir. 2020. "The Importance of Integrity Values as Corruption Prevention Measures." Test Engineering \& Management 83(1):12043-54.

Rosmi, and Syamsir. 2020. "The Influence Of Integrity And Work." International Journal of Research and Analytical Reviews 7(1):774-79.

Salwa, Affah, Yuwaldi Away, and Mirza Tabrani. 2018. "Pengaruh Komitmen, Integritas Dan Kompetensi Terhadap Kinerja Pegawai Serta Dampaknya Pada Kinerja Komisi Independen Pemilihan (KIP) Aceh.” Jurnal Manajemen Dan Bisnis 2(1):58-67. 
Saputra, I. Putu Ari, I. Wayan Bagia, and I. Wayan Suwendra. 2016. "KINERJA KARYAWAN." E-Journal Bisma Universitas Pendidikan Ganesha 4(1).

Sudarwati, S. 2014. "Pengaruh Motivasi, Disiplin Kerja Dan Kompetensi Terhadap Kinerja Pegawai Dinas Pendidikan Kabupaten Sragen.” Jurnal Paradigma Universitas Islam Batik Surakarta 12(01):116176.

Sujiyanto. 2017. "Pengaruh Integritas Dan Loyalitas Pegawai." Jimmu II(2).

Sutrisno, Edy. 2011. Manajemen Sumber Daya Manusia. Jakarta: Kencana Prenada Media Group.

Syamsir, and M. A. Embi. 2020. "Integrity Development through Psm for Corruption Prevention among Public Servant." International Journal of Psychosocial Rehabilitation 24(8):1437-48. doi: 10.37200/IJPR/V24I8/PR280157.

Tasi, Riri, and Syamsir. 2020. "The Influence Of Integrity And Work." International Journal of Research and Analytical Reviews 7(1):774-79.

Umar, A. M., S. Ghalib, and T. Taharuddin. 2016. "Pengaruh Budaya Korporat Terhadap Kinerja Karyawan (Studi Pada PT. Bank Pembangunan Daerah Kalimantan Selatan Kantor Cabang Utama Banjarmasin).” Jurnal Bisnis Dan Pembangunan 1-10.

Wahyuni, Rahma Sri, and Syamsir. 2020. "The Influence of Integrity and Human Resource Management towards Employee Performance.” International Journal of Research and ... 7(1):780-85.

Wetik, Stanislaus Wembly, Baharuddin, and Hasmin Tamsah. 2018. "Analisis Pengaruh Komitmen Dan Integritas Terhadap Kinerja Melalui Kompetensi Pegawai Pada Kantor Kesyahbandaran Dan Otoritas Pelabuhan Kota Manado." YUME : Journal of Management 1(3):137-51.

Wurangin. 2012. Organisasi Dan Manajemen (Perilaku, Struktur, Budaya, Dan Perubahan Organisasi). Bandung: Alfabeta.

Yolanda, Nadya Meidisyah, and Syamsir Syamsir. 2020. "Pengaruh Integritas Terhadap Kinerja Pegawai Negeri Sipil (PNS) Di Lingkungan Organisasi Perangkat Daerah (OPD) Dinas Kota Padang Nadya." Jurnal Perspektif: Jurnal Kajian Sosiologi Dan Pendidikan 3(1):70-77.

Yusnaena, Syahril. 2013. "Pengaruh Integritas Terhadap Kinerja Karyawan Pada Sekretariat Daerah Kabupaten Pesisir Selatan.” Menara Ilmu IX(42):186-91. Zahra. 2011. Manajemen Sumber Daya Manusia. Jakarta: Kencana. 